\title{
Kendali Motor Induksi 3 Fasa Menggunakan Arduino Mega Berbasis HMI (Human Machine Interface)
}

\author{
Eni mariani ${ }^{1}$, dan Hastuti $^{2}$ \\ 1 Universitas Negeri Padang \\ Jl. Prof. Dr.Hamka Air Tawar, 25131, Indonesia \\ enimariani912@gmail.com $^{1}$, hastuti03@gmail.com ${ }^{2}$
}

\begin{abstract}
Phase induction motor is the type of motor that is most widely used to drive various loads / machines. In its installation, a 3-phase induction motor with large power requires a series of starting and controlling such as reversing the direction of rotation, speed regulation and so on. This study aims to create a system that can work as a speed control for an induction motor with a relatively small power supply, and with frequency input via an LCD screen to make it easier and faster to work if the motor is needed to work at a certain speed. Setting the frequency input value on an induction motor can be done using the inverter. The inverter used is a PWM type using an IRFP460N type MOSFET. The frequency is adjusted and changed via the HMI LCD screen display which supports the Arduino UNO and Arduino MEGA microcontrollers. Based on the test results in the laboratory, the induction motor speed control is obtained by varying the frequency input value, operating with a low starting current ranging from 1.1A-1.3A without load, with a minimum frequency value of $40 \mathrm{~Hz}$ and a maximum of $60 \mathrm{~Hz}$, these set points are used based on work data / nameplate printed on the induction motor used. In operation, the DC input voltage to the inverter at the initial start with a frequency value of $40 \mathrm{~Hz}$ is 70 volts and produces a motor rotating speed of $778 \mathrm{RPM}$ reading on the LCD screen. This condition can change based on changes in the setpoint of the frequency value. As a result, controlling the speed of the induction motor can be done based on the value of the frequency and can be adjusted easily via the LCD screen.
\end{abstract}

Keywords-Induction motor, inverter PWM, MOSFET type IRFP460N, Arduino UNO, Arduino MEGA, HMI (human machine interface),

\begin{abstract}
Abstrak- Motor induksi 3 Fasa merupakan jenis motor yang paling banyak digunakan untuk menggerakan berbagai beban/mesin. Dalam instalasinya, motor induksi 3 fasa dengan daya besar memerlukan rangkaian starting dan kendalinya seperti untuk membalik arah putaran, pengaturan kecepatan dan sebagainya. Penelitian ini bertujuan untuk membuat sistem yang dapat bekerja sebagai kontrol kecepatan motor induksi dengan suply daya relatif kecil, dan dengan input frekuensi melalui tampilan layar LCD agar lebih mudah dan cepat pengerjaannya apabila motor dibutuhkan bekerja dengan kecepatan tertentu. Pengaturan nilai masukan frekuensi pada motor induksi bisa dilakukan dengan menggunakan Inverter. Inverter yang digunakan ialah jenis PWM menggunakan MOSFET tipe IRFP460N. Frekuensi diatur dan diubah melalui tampilan layar LCD HMI yang support terhadap mikrokontroller Arduino UNO dan Arduino MEGA. Berdasarkan hasil pengujian di labolatorium diperoleh kendali kecepatan motor induksi dengan memvariabelkan nilai masukan frekuensi, beroperasi dengan arus starting rendah berkisar 1,1A-1,3A kondisi tanpa beban, dengan setpoin nilai frekuensi minimal $40 \mathrm{~Hz}$ dan maksimal $60 \mathrm{~Hz}$, setpoin tersebut digunakan berdasarkan data kerja/ nameplate yang tertera pada motor induksi yang digunakan. Dalam pengoperasiannya, tengangan input DC ke inverter pada start awal dengan nilai frekuensi $40 \mathrm{~Hz}$ ialah sebesar 70 volt dan menghasilkan kecepatan putar motor sebesar 778 RPM pembacaan pada tampilan layar LCD. Kondisi ini dapat berubah berdasarkan perubahan setpoin nilai frekuensi. Hasilnya, pengontrolan kecepatan motor induksi dapat dilakukan berdasarkan besar nilai frekuensi dan dapat diatur dengan mudah melalui tampilan layar LCD.
\end{abstract}

Kata kunci-Motor induksi, inverter PWM, MOSFET tipe IRFP460N, Arduino UNO, Arduino MEGA, HMI (human machine interface)

\section{Pendahuluan}

Salah satu perkembangan teknologi dibidang industri ialah kemudahan dalam pengaturan dan pemrosesan sistem yang ada di lapangan. Hal ini menjadi suatu fokus yang sangat berkembang pesat dalam kemajuan teknologi di industri. Sistem kontrol merupakan salah satu aspek yang sangat mempengaruhi kelangsungan kegiatan produksi serta keamanan alat yang beroperasi [1]. kendala yang ditemui di lapangan ialah sulitnya meninjau permasalahan yang terjadi pada alat yang digunakan dikarenakan keterbatasan akses dilapangan (industri), perlunya penanganan secara cepat dan tepat pada saat terjadi pembebanan pada motor. Oleh sebab itu diharapkan adanya teknologi pendukung yang dapat 
mempermudah pengontrolan sistem secara cepat dan tepat sesuai dengan kebutuhan [2].

Ada berbagai jenis motor listrik seperti motor DC, motor AC, dan motor stepper. Motor induksi AC adalah jenis motor yang paling populer digunakan dalam industri karena konstruksinya yang sederhana, reabilitas, ketahanan dan harganya yang murah. Di industri motor 3 Fasa merupakan motor yang paling banyak digunakan untuk menggerakan berbagai beban/mesin. Dalam instalasinya motor induksi 3 fasa dengan daya besar memerlukan rangkaian starting dan kendalinya seperti untuk membalik arah putaran, pengatura kecepatan dan sebagainya [3]. Motor induksi bekerja dengan prinsip elektromagnetik oleh stator yang dialiri arus listrik. Pengaturan putaran motor induksi dapat dilakukan dengan mengubah jumlah pasang kutub, mengatur tegangan jala-jala, atau dengan mengatur besar kecilnya frekuensi[4]. Pengaturan dengan menggunakan perubahan frekuensi, dapat dilakuan secara lebih halus atau linear sesuai dengan perubahan frekuensinya [5]. nilai masukan frekuensi pada motor induksi bisa dilakukan dengan menggunakan Inverter. Inverter bekerja Secara sederhana untuk AC drive, inverter akan mengubah DC ke AC yang kemudian diatur dengan suatu teknik penyaklaran 'switching' mengubah DC menjadi tegangan dan frekuensi keluaran AC yang bervariasi [6]. HMI (human machine interface) merupakan suatu perangkat pendukung yang bisa menghubungkan operator dengan mesin yang bekerja di industri, HMI dapat berupa pengendali dan visualisasi status, baik dengan manual maupun melalui visualisasi komputer yang bersifat real time [7].

Pada tugas akhir ini, penulis menggunakan HMI sebagai sistem komunikasi antara sistem dengan operator. HMI mempunyai kemampuan dalam hal visualisasi untuk monitoring dan data mesin yang terhubung secara online dan real time [8]. HMI akan memberikan suatu gambaran kondisi mesin yang berupa kecepatan putar mesin induksi dan pengaturan input frekuensi ke motor. Penggunaan HMI dapat mempermudah eksekusi sistem secara cepat dan tepat tanpa adanya interaksi manual dengan kontrol mesin di lapangan [9].

Perlunya penanganan secara cepat dan tepat pada saat terjadi pembebanan pada motor juga melatar belakangi dibuatnya suatu sistem kendali yang memanfaatkan interkoneksi HMI dengan kontroler Arduino UNO dan Arduino MEGA 2560, untuk menentukan nilai frekuensi motor induksi yang digunakan. Penulis akan berfokus pada pemrograman mikrokontroller Arduino MEGA 2560 dan inverter[10].

\section{METODE}

Metode yang digunakan pada tugas akhir ini ialah membuat sistem Kendali Motor Induksi 3 fasa Menggunakan Arduino MEGA Berbasis HMI (Human Machine Interface). Rangkaian daya yang digunakan ialah Inverter yang bekerja mengubah DC ke AC yang kemudian diatur dengan suatu teknik penyaklaran switching mengubah DC menjadi tegangan dan frekuensi keluaran AC yang bervariasi. Inverter yang digunakan ialah jenis PWM.

\section{A.Blok diagram}

Perancangan blok diagram dalam tugas akhir ini bertujuan untuk memudahkan dalam proses perancangan alat. Perancangan dilakukan dengan membuat blok, serta membuat sistem kerja alat dan control alat. Pada gambar di bawah ini dapat dilihat alur perancangan dari masing masing komponen/alat.

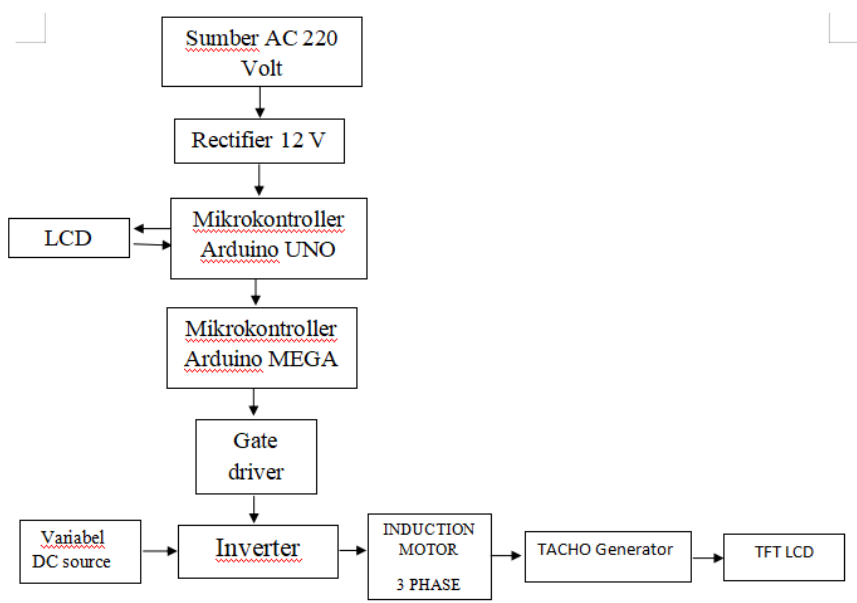

Gambar 1. Blok Diagram Keseluruhan

Berikut penjelasan untuk masing-masing bagian pada blok diagram diatas:

catu daya (rectifier): berfungsi sebagai pengubah tegangan $220 \mathrm{~V}$ dari sumber AC menjadi DC dan menghasilkan tegangan sebesar $12 \mathrm{~V}$ untuk dijadikan supply tegangan ke mikrokontroller. Arduino UNO : digunakan sebagai pengelola input yang diberikan oleh operator melalui tampilan LCD TFT. LCD TFT: berfungsi sebagai penerima input yang diberikan operator melalui layar touch screen dan sebagai penampil data kerja motor. Arduino MEGA: berfungsi sebagai pengelola input dan memproses perintah yang di berikan dan menghasilkan output berupa setting nilai frekuensi pada inverter. Rangkaian gate driver adalah rangkaian untuk meneruskan sinyal kontrol dari keluaran mikrokontroler. Rangkaian ini juga berfungsi sebagai isolasi rangkaian kontrol dan rangkaian daya.

Inverter : berfungsi sebagai rangkaian konversi arus searah (DC) ke arus bolak balik (AC) 3 fasa. Pada penelitian kali ini, inverter juga digunakan sebagai rangkaian yang mengkonversi frekuensi masukan dari sumber untuk menghasilkan nilai frekuensi berdasarkan kebutuhan. Motor Induksi: merupakan objek yang diatur kecepatan kerjanya melalui setting frekuensi masukan.

Tacho Generator : digunakan sebagai sensor pembacaan kecepatan motor induksi pada nilai frekuensi tertentu. Output tegangan keluaran dari tacho generator akan dikonversikan menjadi tegangan ke mikrokontroller arduino UNO untuk ditampilkan pada layar LCD. 


\section{B. Prinsip Kerja Alat}

Prinsip kerja sistem ini secara sederhana dapat digambarkan seperti gambar flowchart di bawah ini

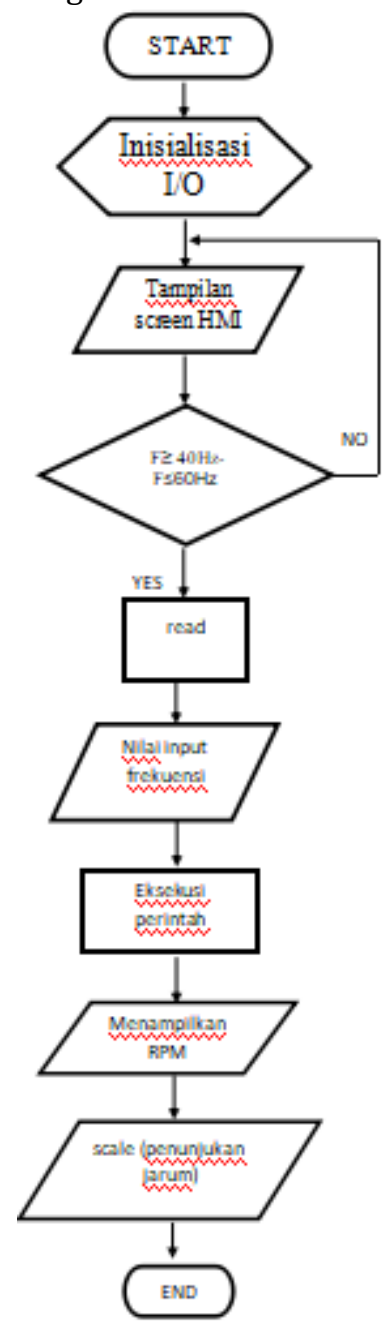

\section{Gambar 2. Gambar Flowchart kerja program}

Keteranagn Flowchart:

Alat sudah terhubung dengan sumber $220 \mathrm{~V}$ sat keadaan start, kemudian mikrokontroller dalam keadaan ready dengan program yang sudah di downloadkan sebelumnya. Saat tombol start on ditekan maka alat akan melakukan inisialisasi I/O dan kemudian tampil menu pilihan pada layar LCD. Tampilan awal LCD berupa keypad angka-angka untuk diinputkan sebagai nilai frekuensi, setelah nilai diinputkan maka akan di proses berdasarkan ketentuan yang sudah ada pada program yang didownloadkan, perintah tersebut diteruskan ke mikrokontroler arduino mega untuk diproses dan dilanjutkan sebagaai perintah kerja inverter, selanjutnya untuk menampilkan data kerja motor di layar LCD, tegangan DC output tacho generator akan di hubungkan ke mikrokontroller arduino uno untuk kemudian diproses dan ditampilkan pada layar LCD. Jika pembacaan nilai RPM pada tacho generator dan tampilan pada layar LCD memiliki perbedaan yang tidak terlalu signifikan, maka pengujian berhasil dan program bekerja dengan baik sesuai dengan perencanaa.

\section{Tampilan Software}

Software yang digunakan pada alat ini menggunakan pemograman mikrokontroller dengan bahasa $\mathrm{C}$ dan sebagai compiler dari program adalah software Arduino IDE. Tampilan pada layar LCD menggunakan program yang sudah di downloadkan pada mikrokontroller Arduino UNO 328. Berikut tampilan pada layar LCD:

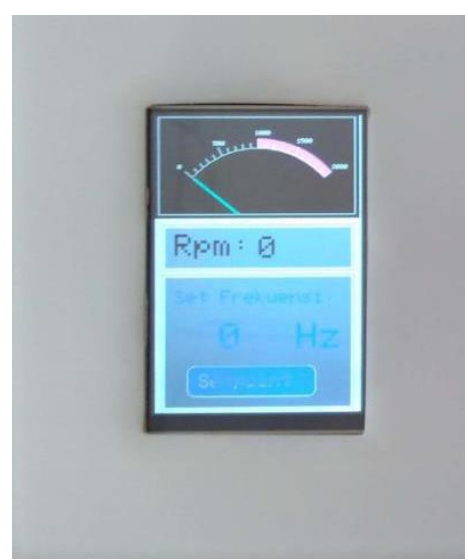

\section{Gambar 3. gambar tampilan layar LCD}

// program Tampilan Awal LCD

tft.reset();

tsID = tft.readID ()

tft.begin(tsID);

tft.invertDisplay(true);

tft.setRotation(Orientation);

tft.fillScreen(GREEN);

tft.drawRect(10, (meterScaling * 126) + 10, 300, 75,

WHITE);

tft.fillRect(15, (meterScaling * 126) + 15, 290, 65,

DARKGRAY);

tft.setTextColor(WHITE, DARKGRAY);

tft.setTextSize(5);

tft.setCursor(30, (meterScaling * 126) + 25);

tft.print("Rpm:");

tft.drawRect(10, (meterScaling * 126) + 90, 300, 220,

WHITE);

tft.fillRect(15, (meterScaling * 126) + 95, 290, 210,

DARKGRAY);

tft.setTextColor(BLUE, DARKGRAY);

tft.setTextSize(3);

tft.setCursor(30, (meterScaling * 100) + 150);

tft.print("Set Frekuensi:");

tft.setTextColor(BLUE, DARKGRAY);

tft.setTextSize(6);

tft.setCursor(100, (meterScaling * 140) + 150);

tft.print(" "); 
tft.setCursor(100, (meterScaling * 140) + 150); tft.print(hz);

tft.setCursor(220, (meterScaling * 140) + 150); tft.print("Hz");

\section{HASIL DAN PEMBAHASAN}

Pada hasil dan pembahasan ini akan dilakukan beberapa pengujian dan anlisa pada seluruh bagian input maupun output. Pengujian mekanik bertujuan untuk membandingkan hasil perancangan pada bab 3 dengan hasil jadi pada pembuatan. Pada perancangan Tugas Akhir ini menggunakan mikrokontroller ATMega2560 (Arduino MEGA) dan mikrokontroller ATMega328 (Arduino UNO) sebagai pusat pengontrolan sistem keseluruhan. Adapun yang akan dikontrol yaitu modul 3.5 ILI9486 TFT LCD touch screen, Inverter, sensor kecepatan dan gatedrive.

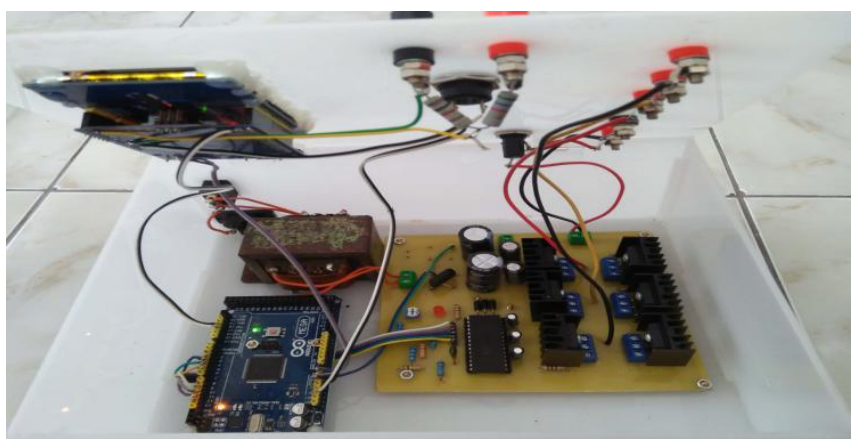

Gambar 4. Bentuk fisik alat tampak dalam

\section{Pengujian Catudaya (Power Suply)}

Catu daya merupakan bagian yang paling utama dan terpenting dalam alat ini, karena catu daya yang nantinya akan memberikan supply daya ke setiap blok rangkaian. Supply tegangan yang digunakan pada rangkaian catu daya yaitu 220 AC yang di dapat dari instalasi PLN. Pengujian rangkaian power supply bertujuan untuk mengetahui apakah tegangan keluaran sesuai dengan apa yang diinginkan yaitu 12 volt dan 5 volt..

Tabel 1. Hasil Pengukuran Tegangan Catu Daya

\begin{tabular}{cclc}
\hline No & $\begin{array}{c}\text { Titik } \\
\text { Pengukuran }\end{array}$ & Pengukuran & $\begin{array}{c}\text { Tegangan } \\
\text { Volt (V) }\end{array}$ \\
\hline 1 & V1 & $\begin{array}{l}\text { Output IC } \\
7812\end{array}$ & 12 VDC \\
\hline 2 & V2 & $\begin{array}{l}\text { Output IC } \\
7805\end{array}$ & 5,3 VDC \\
\hline
\end{tabular}

Dari Pengukuran diatas dapat dianalisa bahwa ketika catu daya aktif maka tegangan yang dihasilkan adalah 5,3 VDC dan 12 VDC, sedangkan ketika catu daya tidak aktif tegangannya 0 volt atau tidak ada. Pengujian catu daya juga digunakan untuk mengetahui berapa tegangan yang digunakan untuk menghitung daya yang dikonsumsi oleh masing-masing komponen yang digunakan pada tugas akhir ini.

\section{Pengujian Rangkaian Komunikasi Mikrokontroller Arduino UNO}

Pengujian pada rangkaian komunikasi mikrokontroller arduino UNO bertujuan untuk mengetahui besar tegangan yang masuk pada sistem minimum tersebut, hal ini dilakukan untuk memastikan rangkaian mikrokontroller dapat bekerja dengan baik dan menerima suply tegangan yang sesuai dengan kebutuhan rangkaaian mikrokontroller. Pengukuran tegangan dilakukan pada arduino yang sudah diberi tegangan 5,2 volt DC dari output power suply sesuai dengan tegangan kerja sistem.

Setelah dilakukan pengujian pada rangkaian mikrokontroller arduino UNO, didapatkan hasil pengukuran seperti pada tabel di bawah ini.

Tabel 2. Hasil Pengukuran Arduino UNO

\begin{tabular}{ccc}
\hline No & Logika Port & Hasil Pengukuran \\
\hline 1 & $0($ Low $)$ & $0 \mathrm{~V}$ \\
\hline 2 & 1 (High) & $5 \mathrm{~V}$ \\
\hline
\end{tabular}

Mikrokontroler arduino UNO memiliki tegangan kerja 5 VDC dan tegangan input yang direkomendasikan antara 912 VDC. Mikrokontroler bekerja pada dua kondisi logika yaitu kondisi low (0) dan high (1). Pada saat kondisi logika low (0) tegangan yang terbaca pada pengukuran didapatkan tegangan sebesar 0 VDC yang berarti tidak ada tegangan masukan dan sistem masih dalam batas ideal.

\section{Pengujian Rangkaian Modul 3.5 ILI9486 TFT LCD}

Pengujian ini dimaksudkan untuk memasikan modul LCD yang digunakan pada rangkaian ini bisa mendapat suply tegangan yang cukup agar dapat menjalankan fungsinya dengan baik. Modul 3.5 ILI9486 TFT LCD membutuhkan tegangan kerja sebesar 5 VDC. Pengukuran dilakukan dengan cara menghubungkan pin LCD ke probe positif multimeter dan menghubungkan probe negatif ke pin LCD.

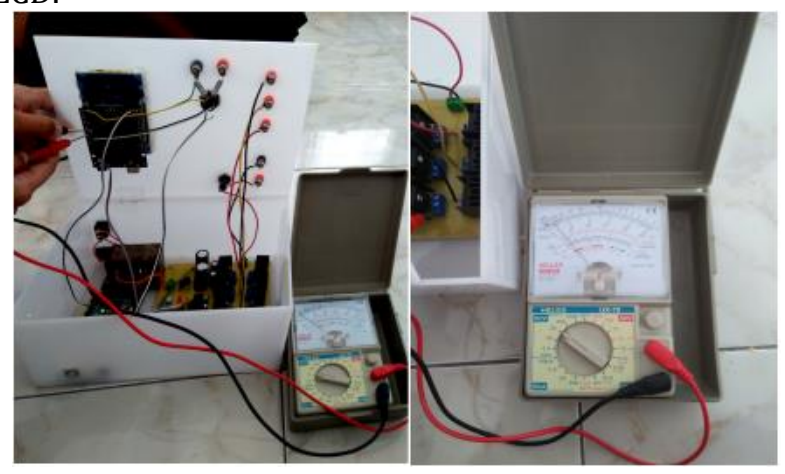

Gambar 5. Pengujian rangkaian Modul 3.5 ILI9486 TFT LCD terhadap Arduino UNO 


\section{Setelah dilakukan pengujian pada pin}

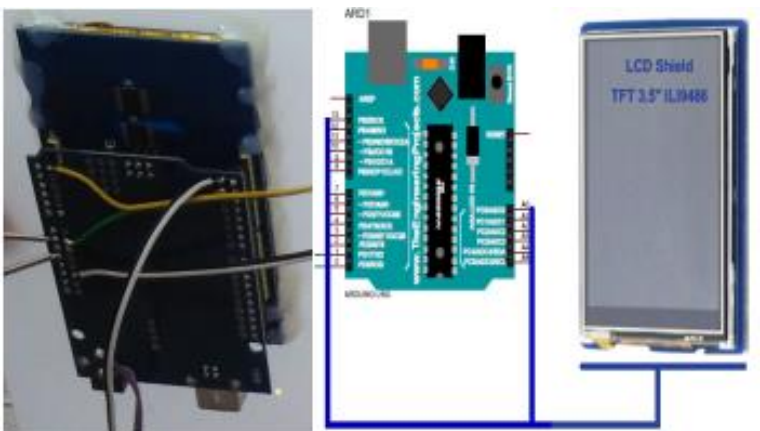

Gambar 6. koneksi rangkaian Modul 3.5 ILI9486 TFT LCD terhadap Arduino UNO

Arduino diprogram untuk dapat memberikan sinyal kelayar berupa tampilan menu setting dan data kerja motor induksi. software yang dipakai dalam membuat program ialah IDE (integrated development environment), program kemudian didownloadkan ke Arduino UNO. Dalam sistem ini arduino akan memproses input yang diberikan dan meneruskan data ke arduino MEGA.

LCD TFT dapat dikatakan bekerja dengan baik bila data yang diberikan dapat di terima dan diproses dengan baik, ketika operator menyentuh permukaan layar LCD saat memberikan perintah input data maka LCD_WR (LCD bus write signal) akan menerjemahkan data tersebut berdasarkan urutan masing-masing pixel pada layar LCD, dan pin LCD_RD (LCD bus read signal) bekerja sebagai pembaca perintah untuk dilanjutkan sebagai ouput data yang diinginkan.

\section{Pengujian Rangkaian Penghubung Mikrokontroller Dengan Inverter}

a. Pengujian tegangan input Mikrokontroller arduino MEGA2560

Pengujian ini bertujuan untuk memastikan bahwa rangkaian mikrokontroller mendapat suply tegangan yang baik, untuk dapat menjalankan fungsinya dengan baik pula. Mikrokontroller arduino MEGA2560 membutuhkan input rekomendasi sebesar 9-12 VDC, dan dengan tegangan kerja sebesar 5 VDC. Pengujian dilakukan dengan menghubungkan probe positif alat ukur multimeter ke pin VCC dan probe negatif dihubungkan ke GND Arduino, seperti gambar berikut

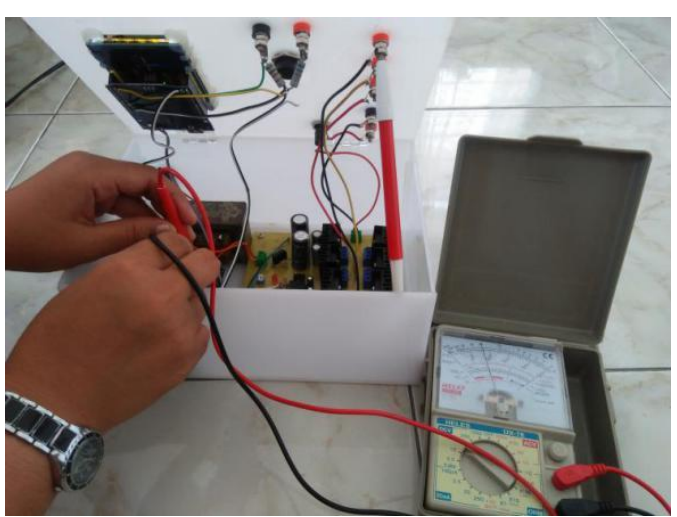

Gambar 7. pengujian rangkaian Mikrokontroller Arduino MEGA2560 terhadap output power suply

Setelah dilakukan pengujian pada port input arduino MEGA, didapati data input tegangan masukan ke arduino MEGA sebesar 12 VDC. Sedangkan untuk tegangan kerja yang terukur sebesar $5 \mathrm{~V}$.

Tabel 3. Hasil Pengukuran Arduino

\begin{tabular}{cc}
\hline Logika Port & Hasil Pengukuran \\
\hline 0 (Low) & $0 \mathrm{~V}$ \\
\hline 1 (High) & $5 \mathrm{~V}$ \\
\hline
\end{tabular}

b.Pengujian Rangkaian Mikrokontroller Arduino Mega2560 Terhadap Ic Gate Drive

Mikrokontroller Arduino MEGA2560 memiliki 15 pin yang bisa digunakan sebagai output PWM, namun pada Tugas Akhir ini penulis hanya menggunakan 6 pin output. Pin komunikasi PWM dihubungkan pada pin masukan IC IR2130 gatedarive. Pengujian ini dilakukan dengan tujuan untuk memastikan arduino dan IC gatedrive terkoneksi dengan baik. Pengujian dilakukan dengan cara menghubungkan probe positif alat ukur multimeter ke salah satu dari 6 pin input ke IC gatedrive secara bergantian dan probe negatif dihubungka ke GND.

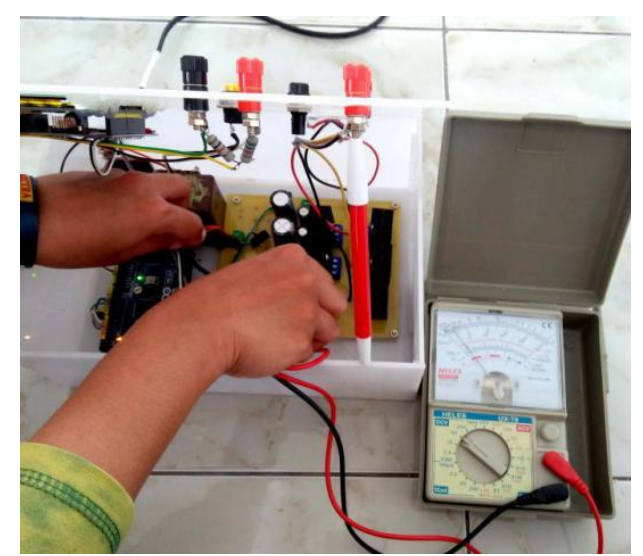

Gambar 8. pengujian koneksi arduino mega ke pin input IC gatedrive 
Selain melakukan pengujian tegangan dengan menggunakan alat ukur multimeter, penulis juga melakukan pengujian menggunkan osciloscop untuk memastikan bahwa bentuk gelombang keluaran PWM sesuai dengan data referensi yang ada.

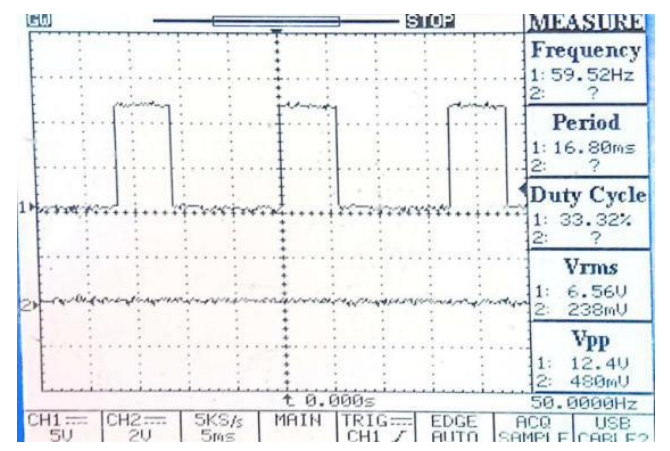

\section{Gambar 9. pengujian output PWM menggunakan osciloscop}

\section{Pengujian Rangkaian Inverter Terhadap Kecepatan Motor Induksi}

Teknik PWM inverter sangat tepat digunakan sebagai implementasi perancangan model. Rangkaian daya inverter tiga fasa yang memiliki enam buah saklar dan sumber tegangan DC. Konverter DC ke AC jenis sumber tegangan (voltage-type inverter) harus memenuhi dua syarat, yaitu saklar yang terletak pada satu fasa tidak boleh konduksi secara bersamaan hingga menimbulkan arus hubung singkat, dan arus sisi AC harus selalu dijaga kontinuitasnya.

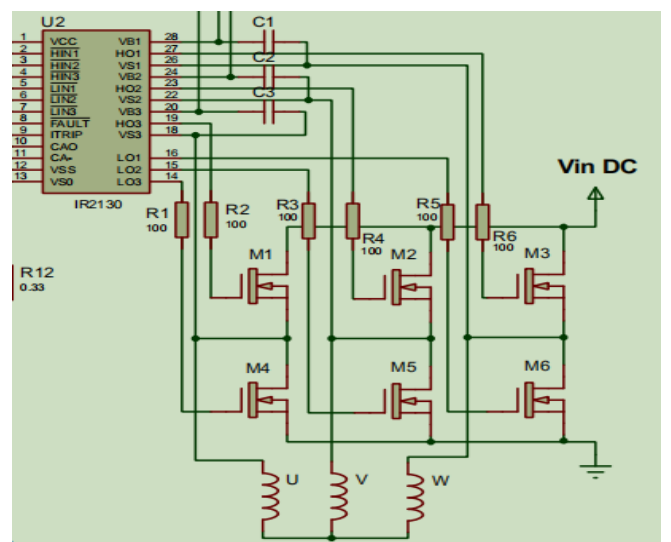

Gambar 10. Konfigurasi inverter 3 phasa 3 lengan

Rangkaian dasar Three Phase Full Bridge Inverter didesain untuk menghasilkan tegangan 380 Vac dan arus 3 Ampere. Untuk memenuhi keadaan tersebut, piranti yang sesuai untuk Three Phase Full Bridge Inverter ini menggunakan MOSFET tipe IRFP 460. MOSFET ini memiliki kemampuan switching diatas $50 \mathrm{KHz}$, batas kemampuan tegangan drain-source sampai $500 \mathrm{~V}$ dan arus drain ID 20 Amper. Setelah dilakukan pengujian secara bergantian pada tiap tiap kaki gate MOSFET untuk mengetahui switching yang terjadi melalui tampilan gelombang pada osciloscop, didapati hasil sebagai berikut

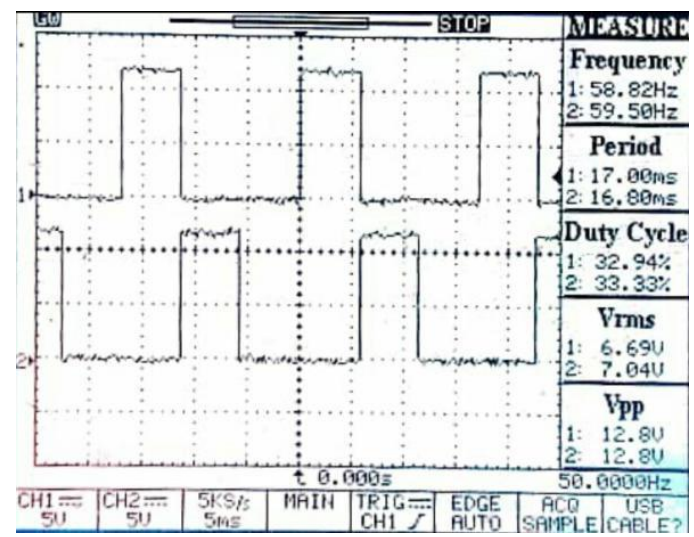

\section{Gambar 11. pengujian output gelombang pada saklar 1 M1 dan M2}

Konfigurasi inverter 3 fasa 3 lengan dibentuk oleh 6 buah saklar daya dengan masing-masing dua saklar berpasangan untuk menghasilkan setiap fasa untuk setiap lengannya. Lengan 1 (MI dan M2) dibentuk oleh saklar M1 pada sisi positif dan saklar M2 pada sisi negatif yang bekerja secara bergantian demikian pula dengan saklar 2 (M3 dan M4) dan 3 (M5 dan M6). Dengan teknik kendali PWM maka konfigurasi saklar daya inverter diatas dapat menghasilkan beberapa kemungkinan pensaklaran.

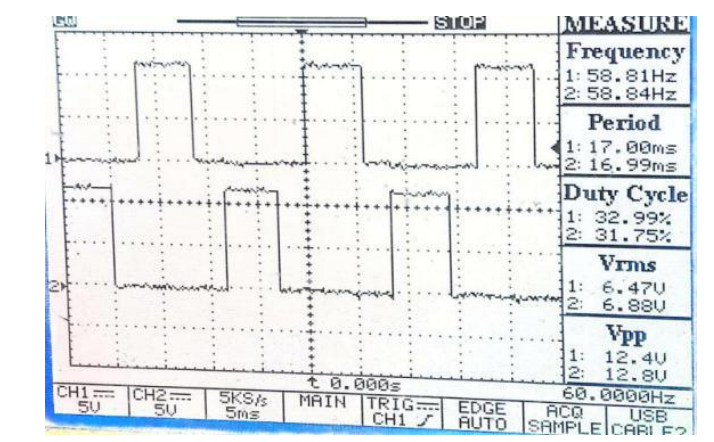

Gambar 12. pengujian ouput gelombang pada saklar 2 M1 dan M3

Gambar berikut merupakan pengujian koneksi 3 fasa output inverter ke kutub motor induksi. 


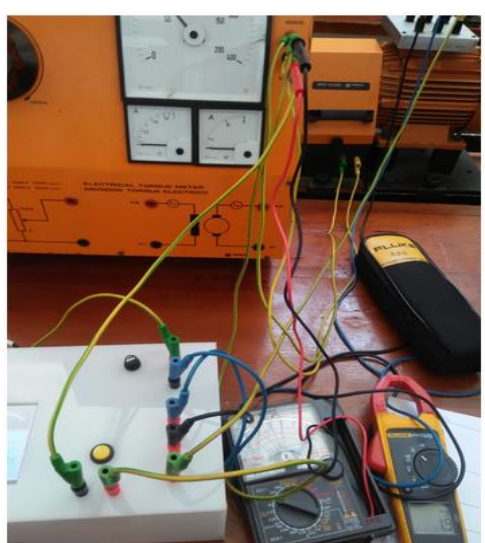

Gambar 13. koneksi 3 fasa output inverter ke kutub motor induksi

Pada pengujian kali ini, output inverter dihubungkan ke kutub motor Induksi, dengan suply DC variabel dari power pack sebagai tegangan referensi ke Inverter. Dari hasil pengujian, didapati hasil seperti pada tabel 6 di bawah ini:

Tabel 4. data pengujian kecepatan motor induksi

\begin{tabular}{ccccccc}
\hline NO & $\begin{array}{l}\text { Vin } \\
\text { (V) }\end{array}$ & $\begin{array}{l}\text { F } \\
\text { (Hz) }\end{array}$ & $\begin{array}{l}\text { I } \\
(A)\end{array}$ & $\begin{array}{l}\text { Vout } \\
(\mathbf{V})\end{array}$ & $\begin{array}{l}\text { RPM } \\
\text { (TG) }\end{array}$ & $\begin{array}{c}\text { RPM } \\
\text { (LCD) }\end{array}$ \\
\hline 1 & 70 & 40 & 1,1 & 13 & 750 & 778 \\
\hline 2 & 80 & 45 & 0,9 & 16 & 950 & 980 \\
\hline 3 & 90 & 50 & 1 & 17 & 1050 & 1100 \\
\hline 4 & 95 & 55 & 1,2 & 19 & 1200 & 1230 \\
\hline 5 & 100 & 60 & 1,3 & 21 & 1250 & 1288
\end{tabular}

Pada data pengujian eksperimental, kecepatan putar motor pada frekuensi $40 \mathrm{~Hz}$ ialah $750 \mathrm{rpm}$ pembacaan alat ukur tacho generator, sedangkan data pengujian pada alat menghasilkan nilai $780 \mathrm{rpm}$ pembacaan dari layar LCD, maka dapat di cari persentaase kesalahan (error) sebagai berikut:

$$
\% \text { Error }=\frac{V(\text { hitungan })-V(\text { terukur })}{V(\text { hitungan })} \times 100 \%
$$

$$
\begin{aligned}
& =\frac{|750-778|}{750} \times 100 \% \\
& =3,7 \%
\end{aligned}
$$

Dari data pengujian di atas dapat dilihat bahwa kecepatan putar motor dapat diatur dengan mengatur input frekuensi ke motor. Pada pembahasan materi mengenai PWM sebelumnya telah dijelaskan bahwa besar nilai frekuensi yang diinputkan akan memengaruhi siklus kerja (duty cycle) PWM dalam satu periode. Satu Periode adalah waktu ON dan OFF penuh dari sinyal PWM.

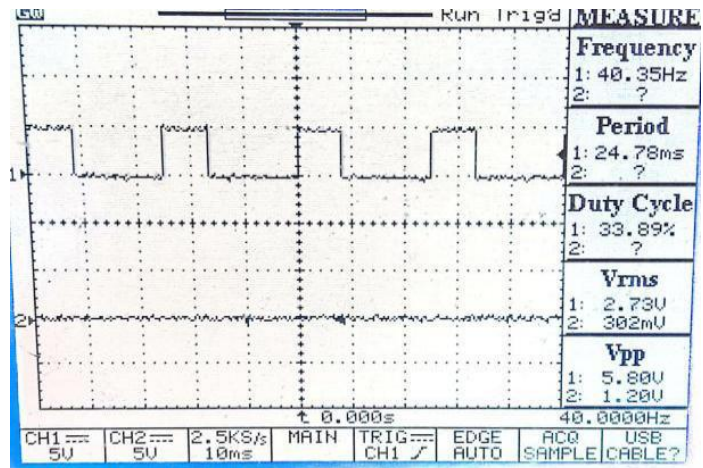

Gambar 14. lebar pulsa PWM ketika frekuensi $40 \mathrm{~Hz}$

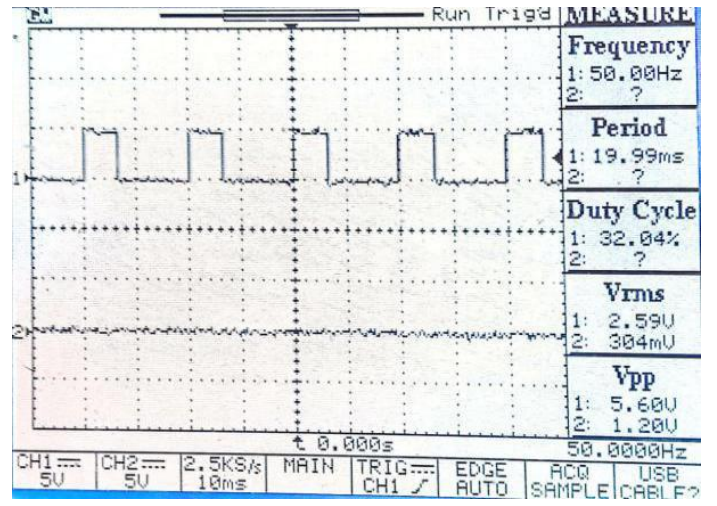

Gambar 15. lebar pulsa PWM ketika frekuensi $50 \mathrm{~Hz}$

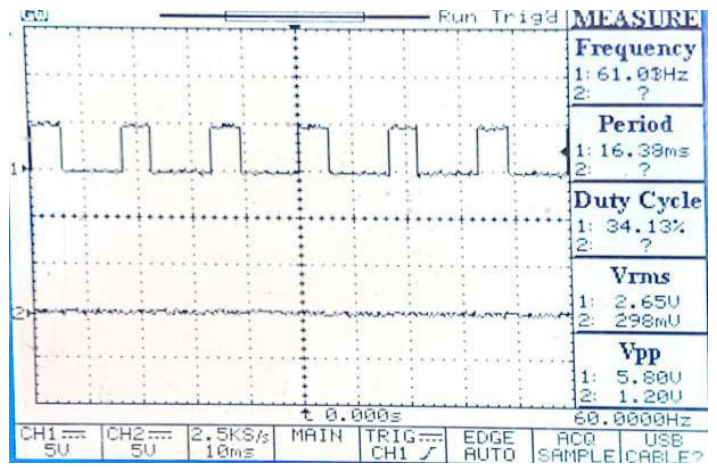

Gambar 16. lebar pulsa PWM ketika frekuensi $60 \mathrm{~Hz}$

Analisa dari hasil pengujian output PWM diatas sebagai berikut:

Diketahui :

Duty Cycle : $34 \%$

Frequency : $61 \mathrm{~Hz}$

Vin : 2,6V

Mencari Time Period atau Periode Waktu :

Time Period $=1 / 61 \mathrm{~Hz}$

Time Period $=0,01$ detik atau 10 milidetik

Mencari Waktu ON (ON-Time) dengan siklus kerja 34\% $(0,34)$

Duty Cycle $=$ tON $/(\mathrm{tON}+\mathrm{tOFF})$ 
$0,34=$ tON $/ 10$ milidetik

tON $=0,34 \times 10$ milidetik

tON $=3,4$ milidetik

Mencari Waktu OFF (OFF-Time)

tOFF $=$ ttotal - tON

$\mathrm{tOFF}=10-3,4$

tOFF $=6,6$ milidetik

Mencari Tegangan Output

Vout $=($ Duty Cycle $\mathrm{x}$ Vin $) /$ periode

Vout $=(34 \% \times 2,6 \mathrm{~V}) / 10$

Vout $=8,84 \mathrm{~V}$

$\%$ Error $=\frac{V(\text { hitungan })-V(\text { terukur })}{V(\text { hitungan })} \times 100 \%$

$$
\begin{aligned}
& =\frac{|8,8-5,8|}{8,8} \times 100 \% \\
& =34 \%
\end{aligned}
$$

Dari data pengujian menggunakan osciloscop, VPP pada saat frekuensi $61 \mathrm{~Hz}$ adalah 5,8V, nilai ini lebih kecil dari data hasil pengujian menggunakan rumus sehingga dapat di simpulkan bahwa error yang terjadi sebesar $34 \%$. Berikut ini merupakan gambaran kurva yang menunjukkan perbandingan nilai frekuensi terhadap kecepatan putar motor induksi, garis horizontal biru merupakan penunjukan nilai rpm terhadap niali $\mathrm{Hz}$.

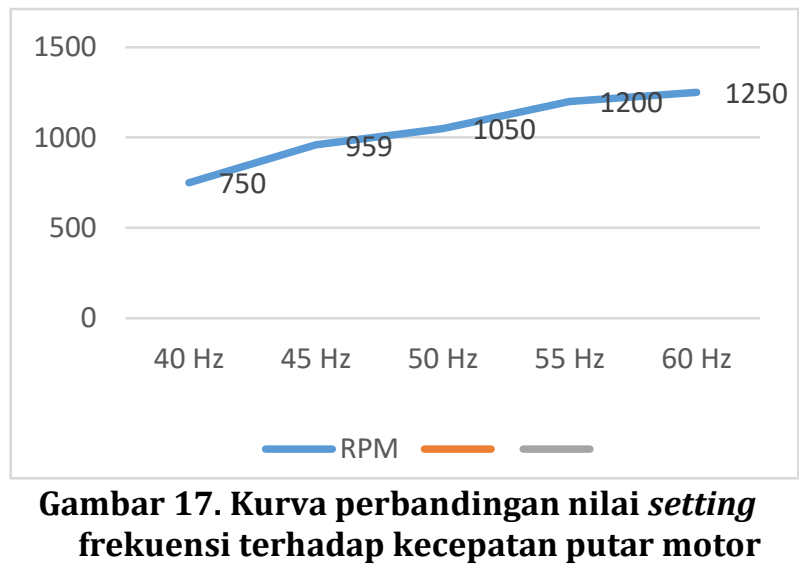

\section{PENUTUP}

Berdasarkan hasil pengujian dan analisa hardware dan software pada kendali motor induksi 3 fasa menggunakan arduino mega berbasis hmi (human machine interface) maka kesimpulan pada penelitian kali ini ialah penggunaan 3.5 ILI9486 TFT LCD touch screen sebagai modul pada sistem HMI dinilai dapat bekerja dengan baik dan sesuai pada perencanaan penggunaan tugas ahir ini. Tampilan layar LCD dapat diatur berdasarkan kebutuhan.

Ketika frekuensi input ke motor disetting $40 \mathrm{~Hz}$ maka Vin minimum yang dibutuhkan ialah 70 VDC dengan arus sebesar 1,1A. ketika frekuensi input ke motor disetting $50 \mathrm{~Hz}$ maka Vin minimum yang dibutuhkan ialah 86 VDC dengan arus sebesar 0.9A, artinya semakin besar input frequnsi yang diberikan maka semakin besar pula daya yang dibutuhkan. Kecepatan putar motor induksi dapat dikontrol dengan mengubah nilai masukan frekuensi. Data

kecepatan putar motor yang tampil pada layar LCD bukanlah nilai konstan dikarenakan sumber dari tacho generator juga berubah-ubah.

\section{Referensi}

[1] Z. Zulfikar and N. Evaliana, 'Analisis Perubahan Kecepatan Motor Induksi 3 Phasa dengan Menggunakan Inverter 3G3MX2', SEMNASTEK UISU, vol. II no 4, pp. 174-177, 2019.

[2] phuc thinh and tien tan, 'sensorless vector control of AC induction motor using sliding-mode observed', Intern. J Sci Eng, vol. IV NO 2, 2013.

[3] muchamad rifa, 'implementasi komunikasi data pada sistem kendali motor induksi tiga phasa', Pros. Konf. Ilm. Mhs. Unissula Kimu 2, oktober 2019.

[4] priswanto, priswanto, 'penerapan plc hmi (human machine interface ) untuk monitoring objek pada sistem konveyor', Pros. Semin. Nas. Dan Call Pap., vol. VIII no 2, pp. 1-11, Nov. 2018.

[5] m.suyanto and subandi, subandi, 'kendali putaran motor asinkrom 3 phasa dengan vsd tipe atv312hui5n4', Semin. Nas. Teknoka, vol. VOL IV, pp. 89-96, 2019.

[6] zuriman anthony, 'studi pengaruh perubahan frekuensi sumber terhadap faktor daya motor induksi 3-phasa', J. Tek. Elektro, vol. vol II no 2, Jul. 2013.

[7] D. A. Putra, 'Perbandingan Tegangan Keluaran Serta Konsumsi Daya pada Pembangkitan Tegangan Tinggi FrekuensiTinggi', Transient, vol. 4, p. 4, 2015.

[8] P. Manchanda, 'DC Tesla Coil Construction and Applications', Ijraset, vol. 4, no. VII, pp. 579-584, Jul. 2016.

[9] C. Ariwibowo, 'Perancangan Inverter Dual Conversion Push Pull-Full Bridge pada Aplikasi Fotovoltaik', Univ. Diponegoro Semarang, 2010.

[10]W. Mujahid, 'Perancangan Pembangkit Tegangan Tinggi AC Frequensi Tinggi Dengan Kumparan Tesla Menggunakan Inverter Jenis Push-Pull', Jan. 2011.

\section{Biodata Penulis}

Eni Mariani, lahir di sariak, 7 Juni 1998. Menyelesaikan studi DIV Teknik Elektro Industri pada Jurusan Teknik Elektro Fakultas Teknik Universitas Negeri Padang.

Hastuti S.T, M.T, lahir di Tembilahan, 25 Mei 1976. Menyelesaikan studi S1 Sarjana Teknik di Jurusan Teknik Elektro Universitas Andalas. Memperoleh gelar Master Teknik di Sekolah Teknik Elektro dan Informatika (STEI) ITB bidang Sistem Kendali. Staf pengajar di jurusan Teknik Elektro FT-UNP sejak tahun 2008 s.d sekarang. 